\title{
إحداد المطلقة
}

\section{مكتوبرة/ حياتً بنت عبدالأم بنا محهد المهلقاق}

أستاذ مشارك بجامعة الأميرة نورة بنت عبدالرحمن

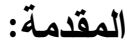

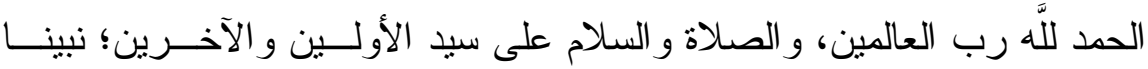
محمد، و على آله وصحبه أجمعين. أما بعد:

فقد أجمع أهل العلم على إباحة الطلاق ،و أنه حل لكثثر من المشكلات الزوجية ،حيــث

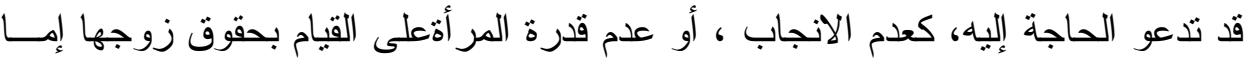

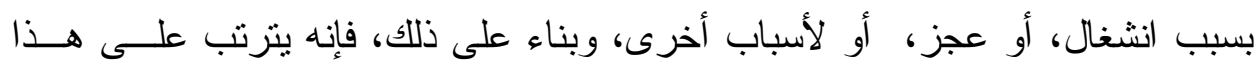

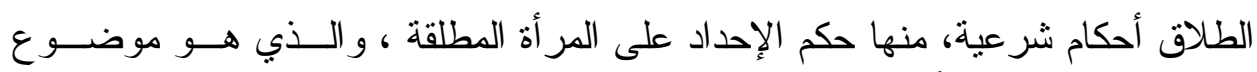

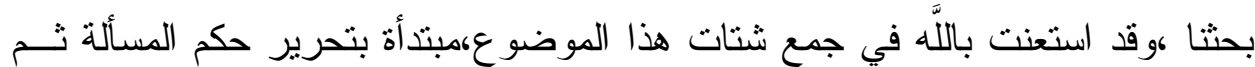
أقو ال فقهاء المذاهب وأدلتهم مع المناقتة و الترجيح، ولعل القارئ الكريم يجد بغيته عند قر اءة البحث ،فقد اجتهدت في بحثي حسب الأمكان.

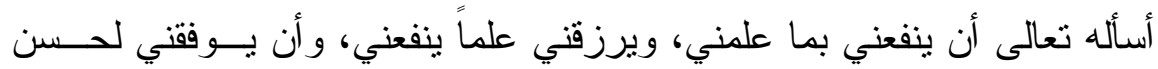
الفهم و الدر اسة، و النظر ، وأن يجعل هذا العمل خالصاً لوجها لونه الكريم. منهج البحث

سلكت في كتابة هذا البحث المنهج الآتي: 1 - الاستقر اء لآز اء الفقهاء في النازلة. Y - الاعتماد على المصادر الأصيلة للبحث. r- عند تتاول المسائل الفقهية اذكر أقوال الفقهاء من ائمة المذاهب الأربعة وابن حزم الظاهري ومن يؤيدهم من العلماء المعاصرين ،واذكر بعد كل قول ما يعضده من

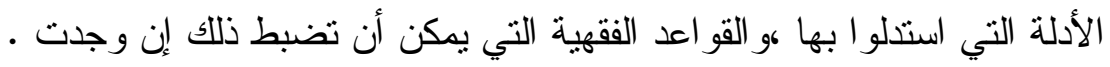
ع - نوثيق نصوص العلماء وآر ائهم من كتبهم مباشرة إلا إذا تعذر ذللك. 


$$
\text { ه - عزو الآيات القر آنية ببيان اسم السورة، ورقم الآية. }
$$

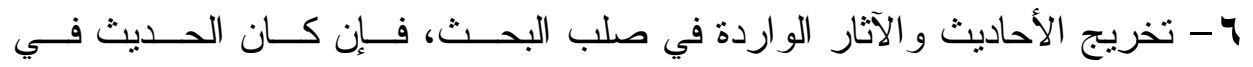

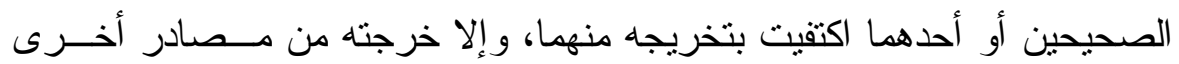

$$
\text { معتمدة، مع بيان ما قاله أهل الحديث فيه. }
$$

- V

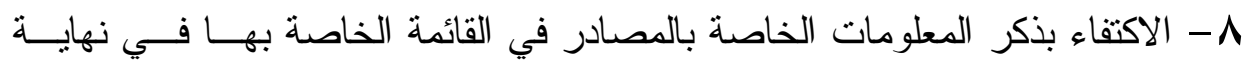

$$
\text { البحث دون ذكر شيء من ذلك في الهامش. }
$$

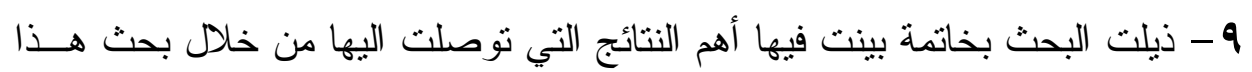

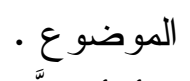

و أسئل اللَّه التوفيق و السداد، إنه سميع قريب مجيب، و لا حول، و لا قوة إلا باللَّــهـ

$$
\text { خطة البحثي العظيم. }
$$

يشنمل البحث على مقدمة، وتمهيد ومبحثين، وخاتمة.

\section{المقدمة:}

ونتنتمل على أهمية البحث، ومنهجه، وخطته.

التمهيد:وفيه التعريف بمفردات العنوان البهيه

$$
\text { وفيه مطلبان: }
$$

المطلب الأول: تعريف الإحداد في اللغة، و الاصطلاح.

المطلب الثاني: تعريف الطلاق و أقسامه وفيه مسألتان:

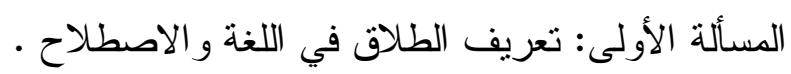

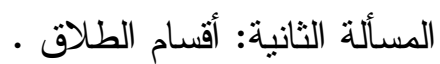

حكم إحداد المطلقة وفيه مبحثان :

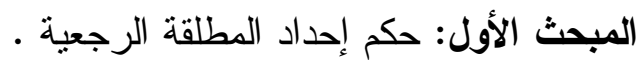

المبحث الثاني: حكم إحداد المطلقة البائنة وفيه مطلبان :

المطلب الأول: المطلقة البائنة قبل الدخول المبات

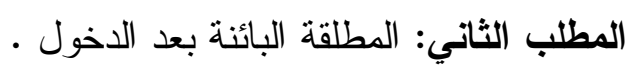


وفيها أهم النتائج و التوصيات، ثم الفهارس.

هذا وأثنكر اللَّه تعالى أن يسر لي هذا البحثن، و وأسأله سبحانه التوفيق و السداد، إنه

ولي ذللك، والقادر عليه وصلى اللَّه وسلم على نبينا محمد، و على آله وصحبه أجمعين. 
التمهيد في التعريف بمفردات العنوان ·

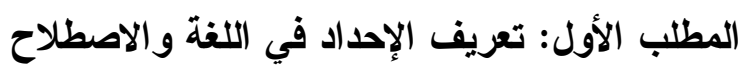

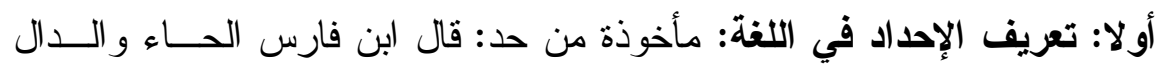

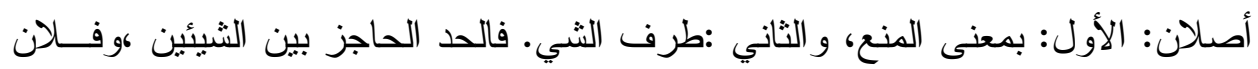

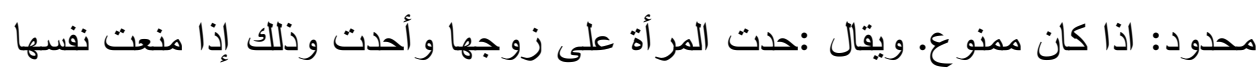
الزينة و الخضاب.

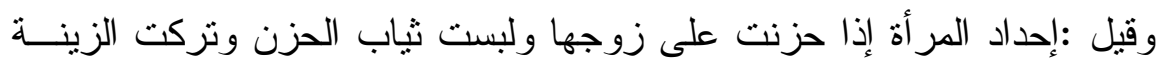

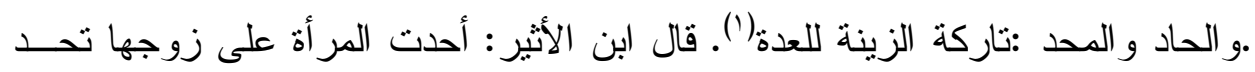

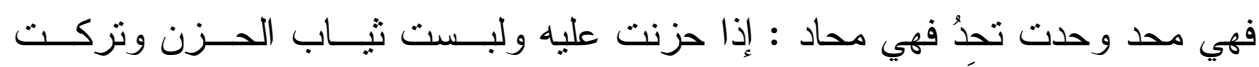

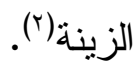

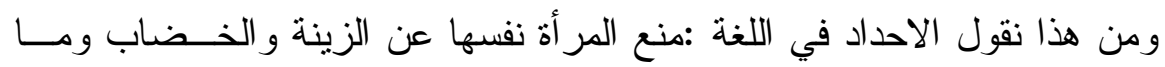

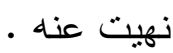

الإحداد في الاصطلاح:عرفه الحنفية بأنه: أن تـــــك المــــرأة الطيــب و الزينــة

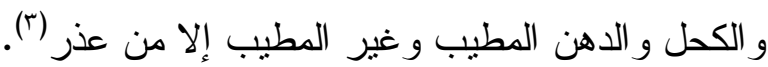

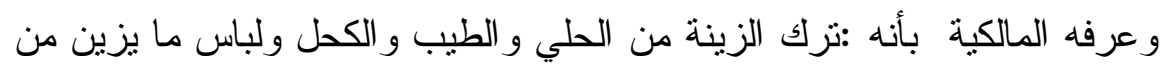

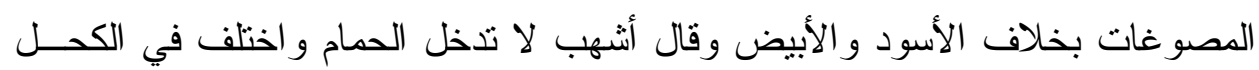

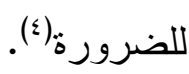

وجاء تعريفه عند الثافعية بأنه : الإمتتاع عن الزينة من لباس وغيــر لبــاس إذا

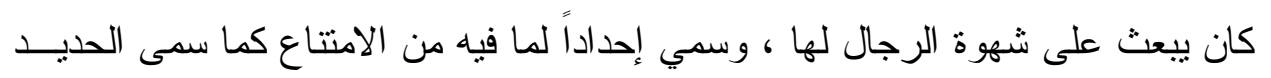

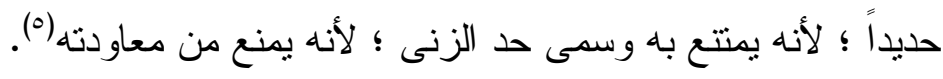

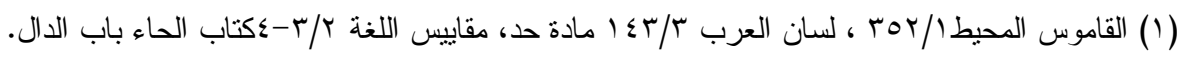

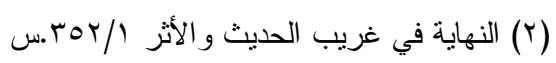

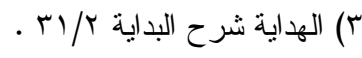

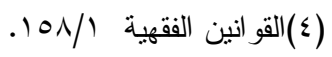

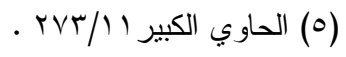


وعرفه الحنابلة بأنه : اجتتاب الزينة و الطيــب و البيتوتسـة فـي غيــر منزلهـــا

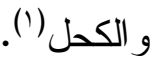

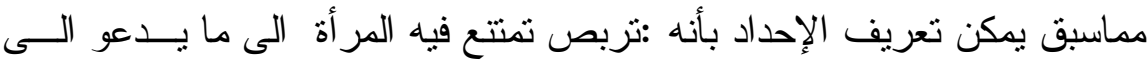

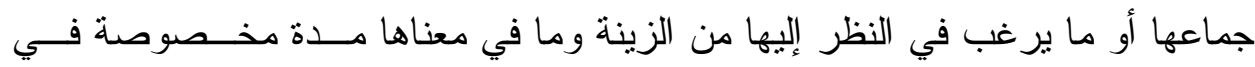

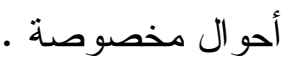

المطلب الثاني: تعريف الطلاق و أقسامه . المسألة الأولى :تعريف الطلاق في اللغة و الاصطلاح

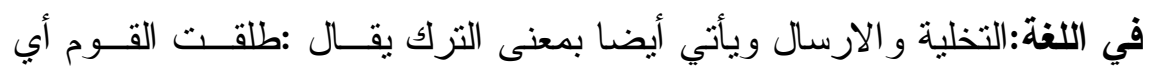

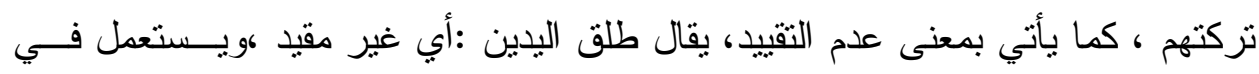

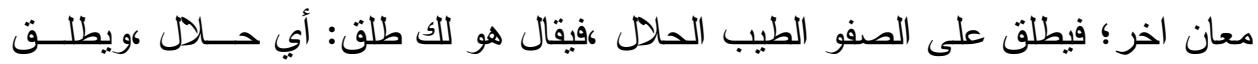

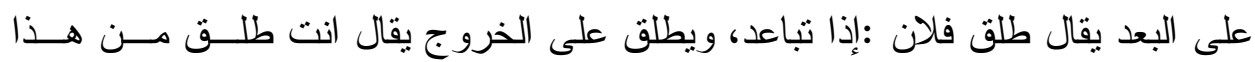

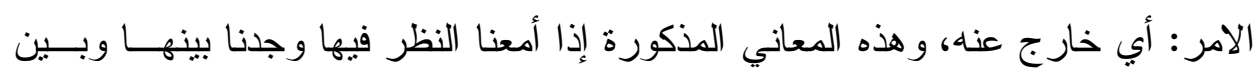

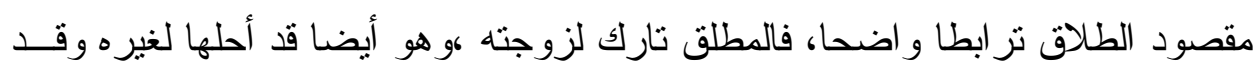

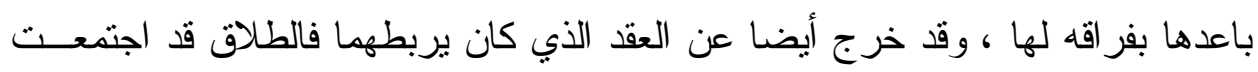

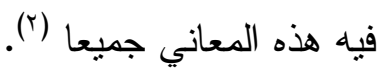
وفي الاصطلاح: عرف الفقهاء الطلاق بعدة تعريفات منها :

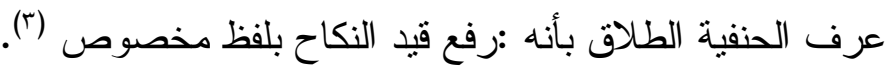

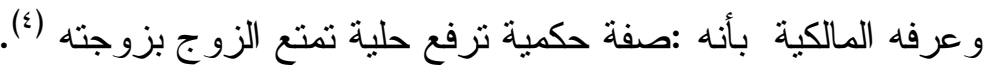
وعرف الثافعية الطلاق بأنه :حل قيد النكاح بلفظ الطلاق (ْ).

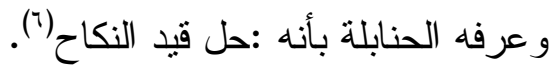




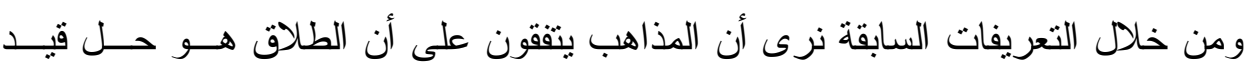

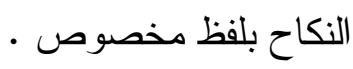

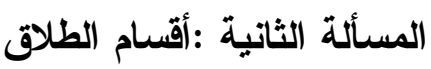
ينقسم الطلاق باختلاف اعتبار ات متعددة :

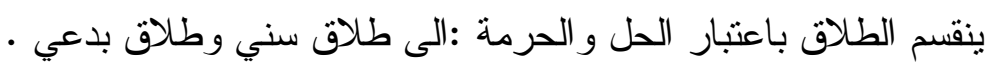
وينقسم باعنبار الرجعة و عدمها :الى رجعي وبائن .

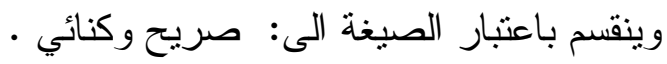

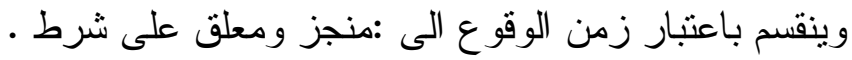

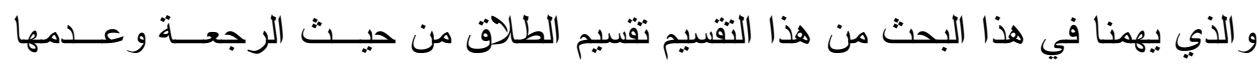
فالطلاق نوعان طلاق رجعي وطلاق بائن .

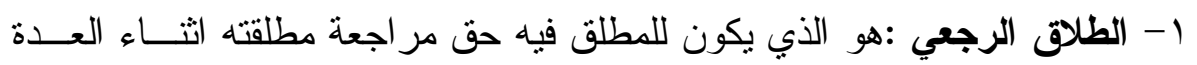

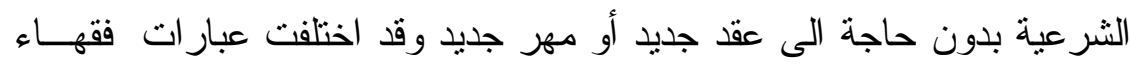

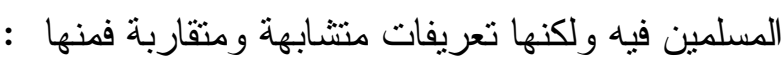

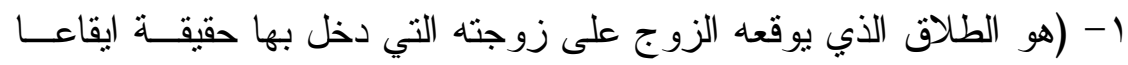

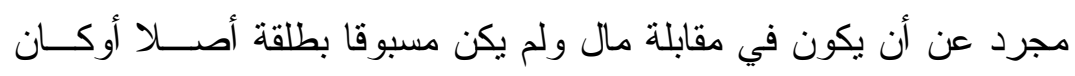
مسبوقا بطلقة و احدة (') ).

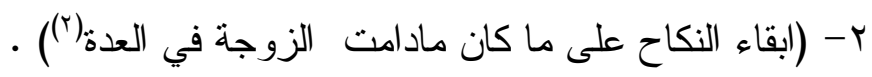

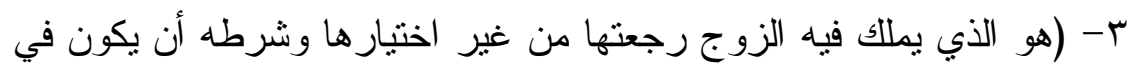

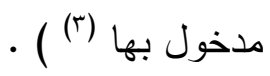

ـ- (هو الذي يكون فيه الزوج مخير ا مادامت في العدة بين تركها لا ير اجعهــا

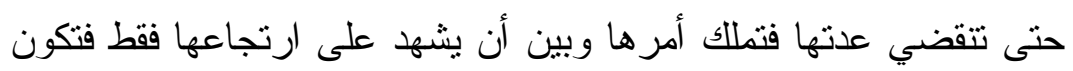

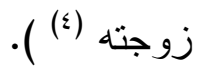

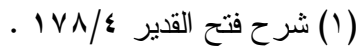

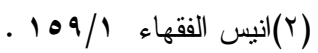

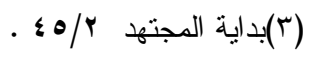

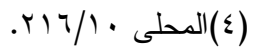


r- الطلاق البائن :معناه المنفصل الذي يفصل بين الزوجة وزوجها علــى الفــور

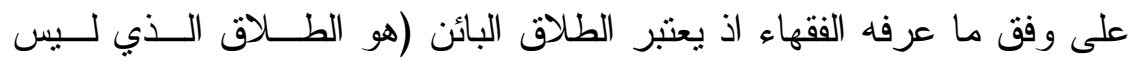

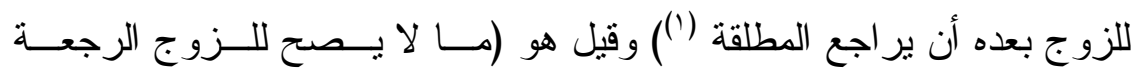

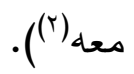

وقيل :(الهطلقة البائنة هو التي لا رجعة لزوجها عليها لكونها مطلقة ثلاثـا أو

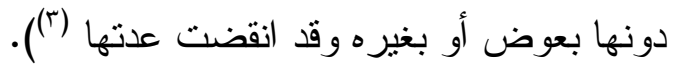
و الطلاق البائن على ضربين : بيرهن 1- البائن بينونة صغرى :و هو الذي يجوز للزئن اللزوج الرجوع الى زوجته بعقد

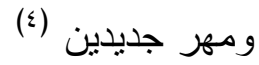

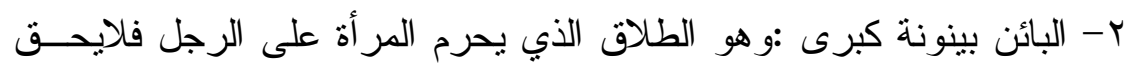

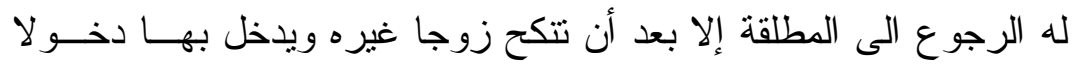

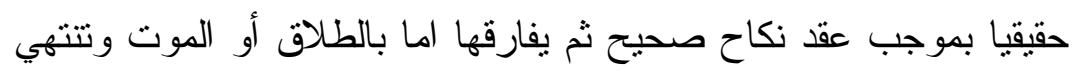

عدنها (०)

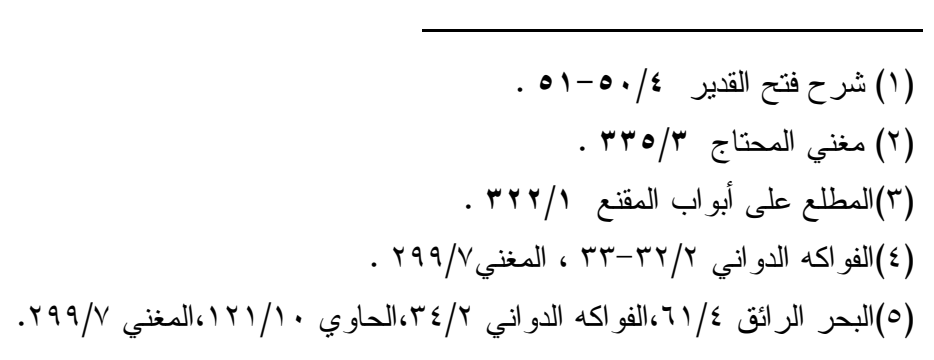




\section{حكم إحداد المطلقة}

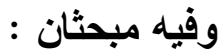 \\ المبحث الأول:حكم إحداد المطلة الرجية : الرجية}

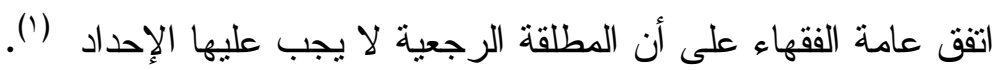

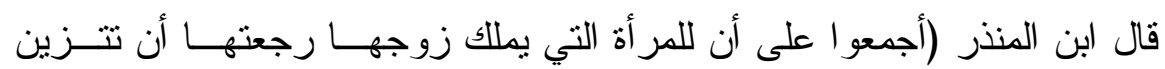
وتتشوف (r) (بن)

وقال ابن حزم :(و لا خلاف في أنه لا إحداد على الرجعيـة لا فــي العـدة و لا

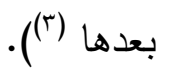
قال النووي (أجمعو ا على أنه لا إحداد على أم الولد و لا على الأمسـة اذا تـــوفي عنهما سيدهما و لا على الزوجة الرجعية (£)).

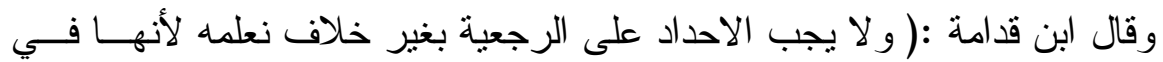

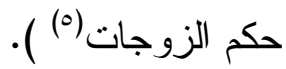

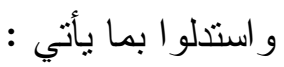

$$
\begin{aligned}
& \text { - - أنها زوجة في الأحكام فلا يجب عليها الاحداد (؟). }
\end{aligned}
$$

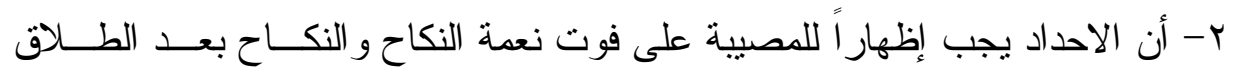

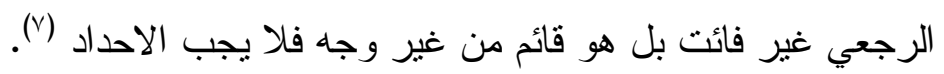

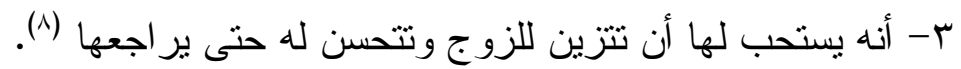

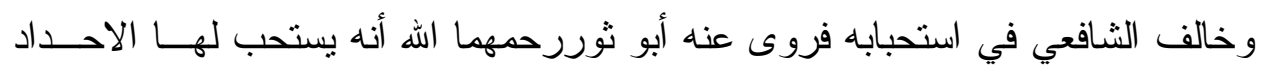

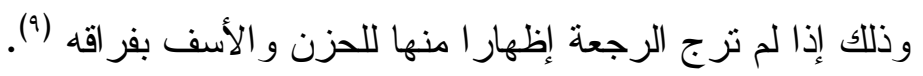

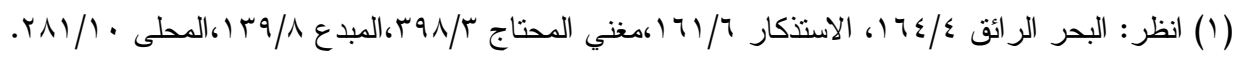

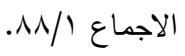

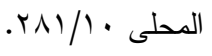

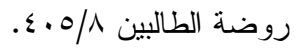

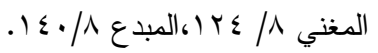

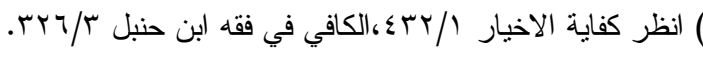

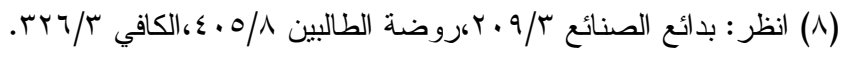

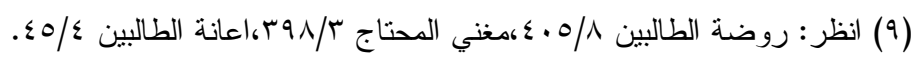




\section{المبحث الثاني : حكم احداد المطلقة البائنة \\ وتحته مطلبان :}

المطلب الأول :إحداد المطلقة البائنة قبل الاخول

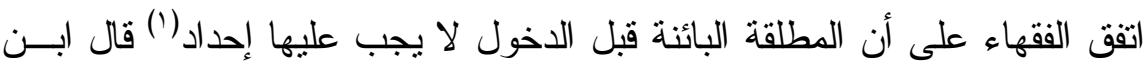
حجر : (المطلقة قبل الدخول لاإحداد عليها اتفاقا (r)) . ولم يوجب العلماء الإحداد على المطلقة البائنة قبل الدخول للأسباب التالية :

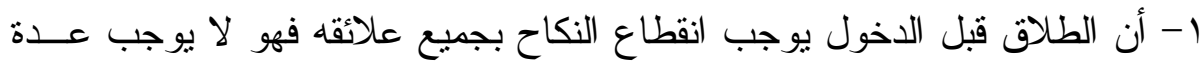

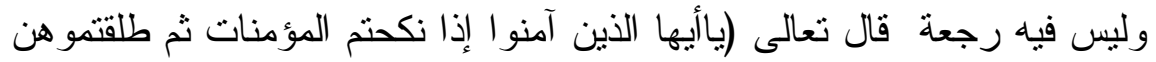

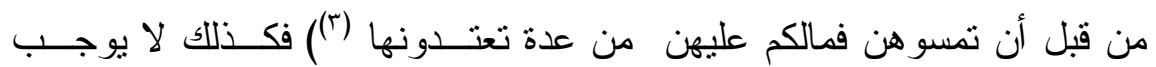

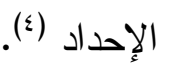
r- أن الإحداد إنما شرع في حق الميت احتياطا للأنساب و الطلاق قبل الدخول قـام

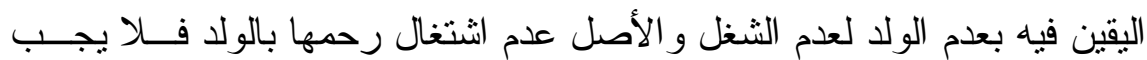

\section{عليها الإحداد (ن)}

المطلب الثاني : حكم إحداد المطلقة البائنة بعد الاخول اختلف الفقهاء في إحداد المطلقة البائنة بعد الدخول فيه ثلاثة أقو ال :

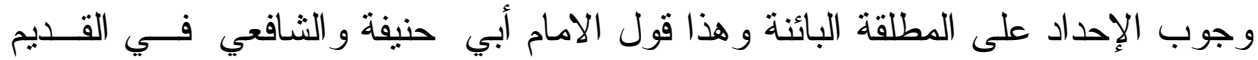
و الامام احمد في احدى الروايتين عنه وبه فال سعيد بن المسيب وأبو عبيد وأبــو ثــور

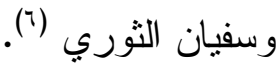
استحباب الإحداد قياسا على إحداد المعتدة عدة وفاة و إلى هـــذا ذهـــب الــشافعية قــال

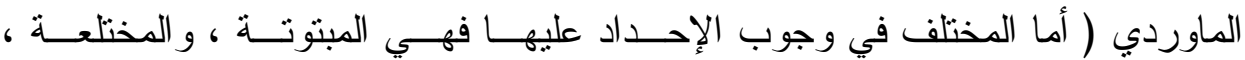

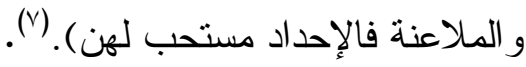


لا إحداد على المطلقة البائنة و إلى هذا ذهب الجمهوروهم المالكية والثافعي في الجديد

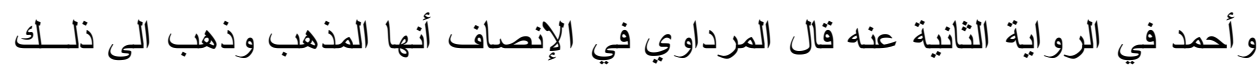
الظاهرية وبه قال عطاء وربيعة و ابن المنذر (').

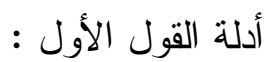

ماروي عن النبي صلى الله عليه وسلم (أنه نهى المعتدة أن تختضب بالحناء(؟) ) .

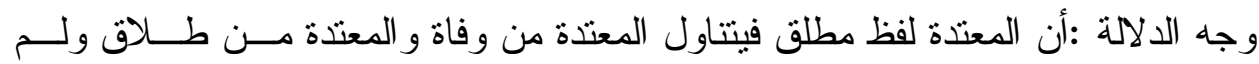

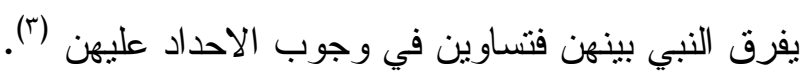
نوقش بالاتي: أن الحديث ضعيف لا تقوم به حجة و لا يحتج به في الأحكام .

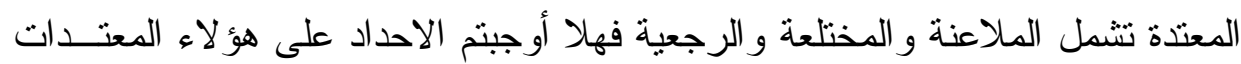

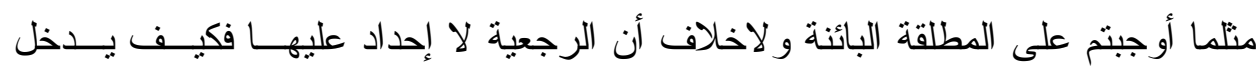

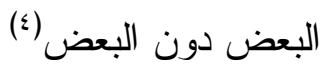
روى الطحــاوي في شرح الآثــار بإسناده إلى حماد عــن إبـــر اهيم قــال: "المطلقــة

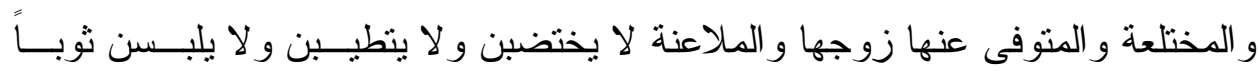

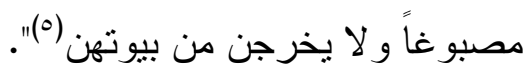

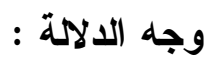
إبر اهيم أدرك عصر الصحابة وز احمهم في الفتوى فيجوز تقليده(?).

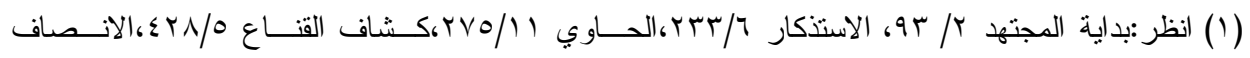

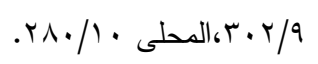
(r) قال الحافظ ابن حجر : ((وروى النسائي بلفظ ( نهى المعتدة عن الكحل و الدهن و الخضاب بالحناء) وقــال

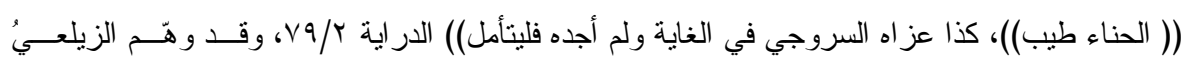

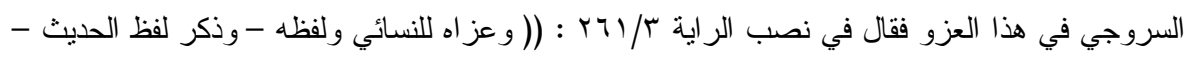

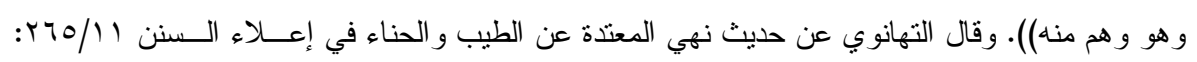

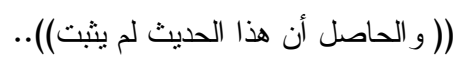

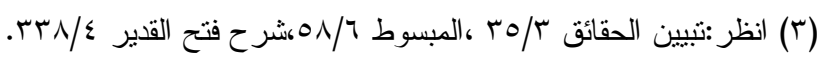

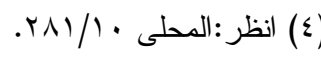
. $11 / r$

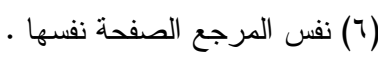


نوقش :

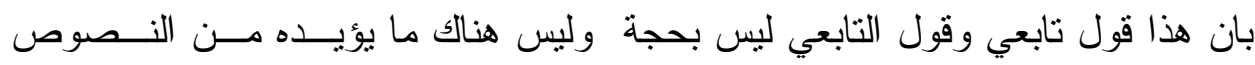

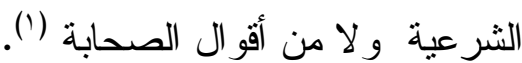
قياس المعتدة البائنة على المتوفي عنها زوجها بجامع انهما معتدتان عن نكــاح لاســبيل

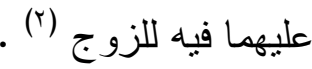
نوفش بالاتي : القياس قياس مع الفارق فهو باطل فالعلة في وجوب الاحداد وقوع الفرقة بعــد اســتيفاء

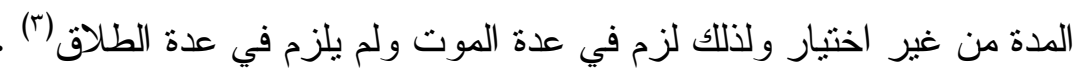

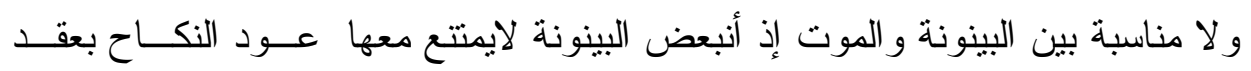
جديد كبينونة الخلع و الفسخ بخلاف الموت فانه لايتصور معه عود النكاح بعده(أ) .

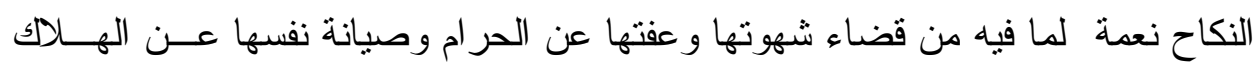

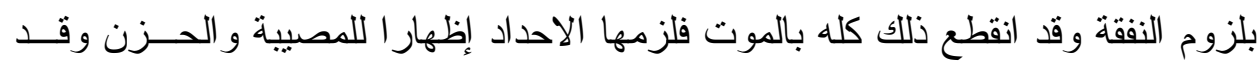

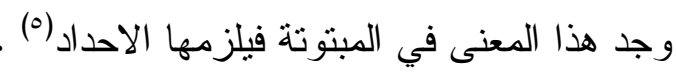

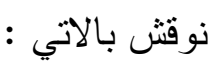
أن نعمة النكاح في المنوفي عنها زوجها ظاهرة امـا البائنة فقد قطع الرجل نكاحها فــالا

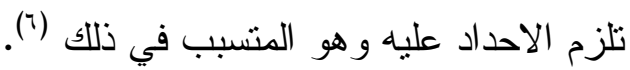

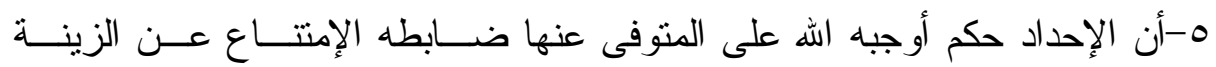

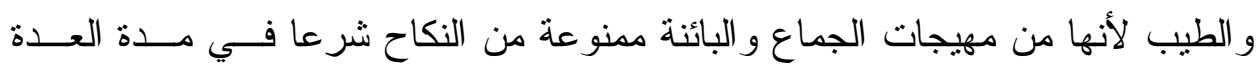

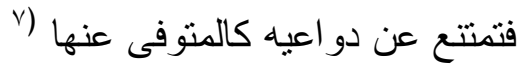
ج-أن المنوفى عنها زوجها و البائنة في عدة يحفظ بها النسب فكانا سو اء في الأحكام (^).

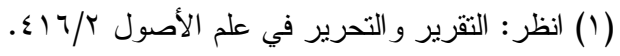

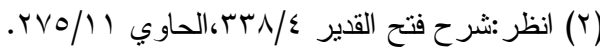

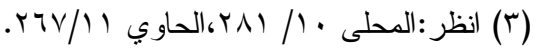

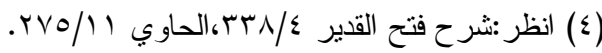

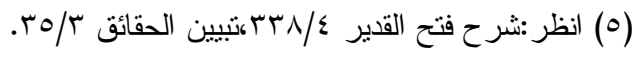

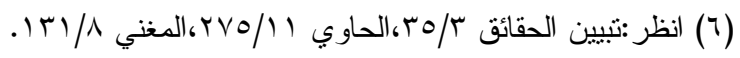

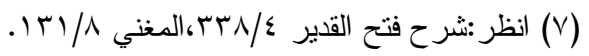

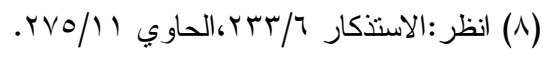


نوفش بالاتي :

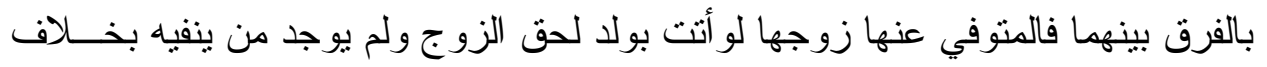

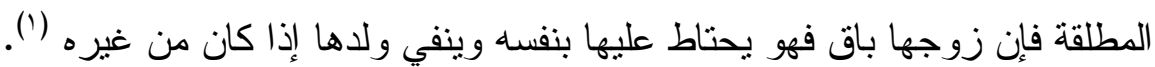

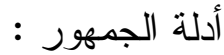
حديث النبي صلى الله عليه وسلم قال :( لا يحل لأمر أه تؤمن بالله واليوم الآخر أن تحد

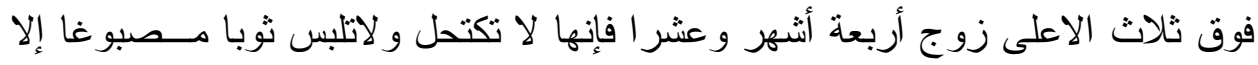

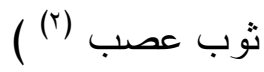

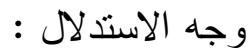
أن الاحداد إنما ورد عن المتوفي عنها زوجها والمطلقة زوجها حي فــلا إحــداد علــى الته

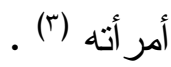

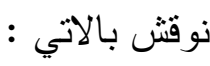
بأنه ليس في الحديث إلا قوله لا يحل لامر أة أن تحد على ميت وليس فيه لا يحل لها أن

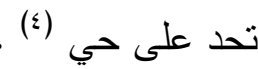
أن الحديث الوارد في المتوفي عنها إنما هو للبيان وليس على سبيل الحصر (ن)

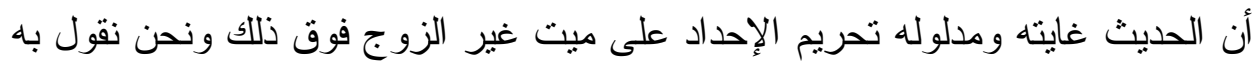

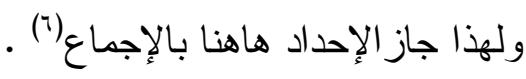

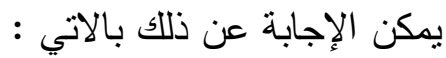

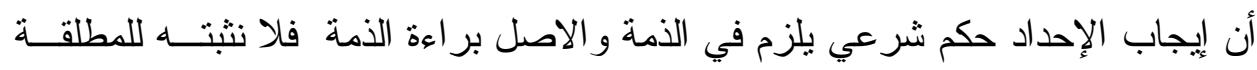
المبتوتة إلا بنص شرعي ولم يوجد (لإن.

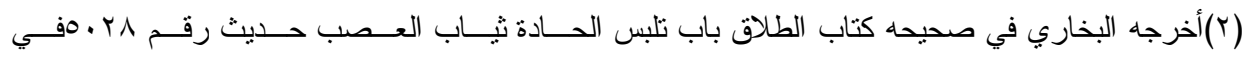

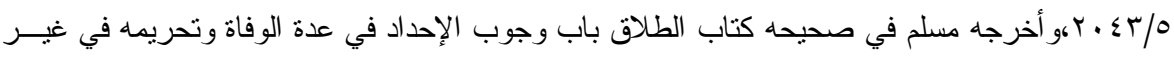

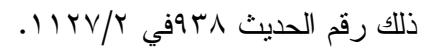

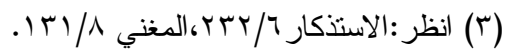

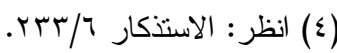

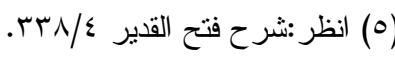

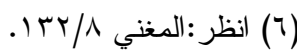

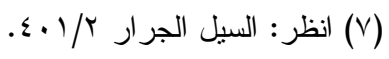


ץ-أن الإحداد إنما وجب على المتوفي عنها زوجها لحق الزوج تأسفا على مافاتها مـن

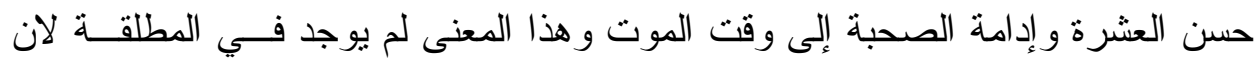

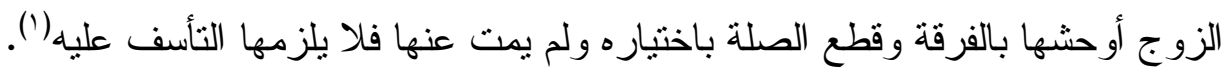

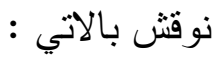

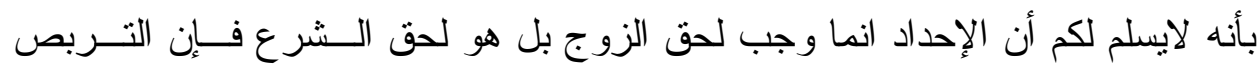

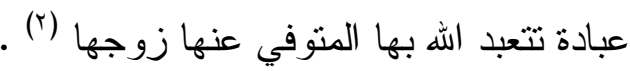

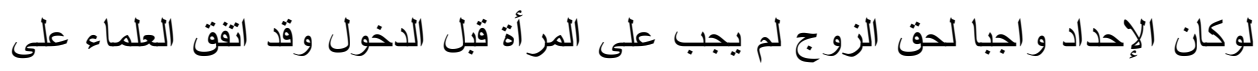

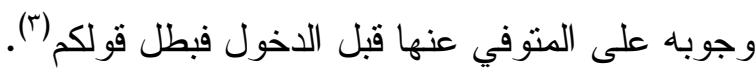

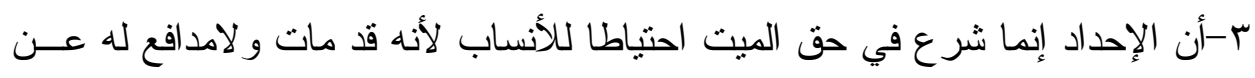

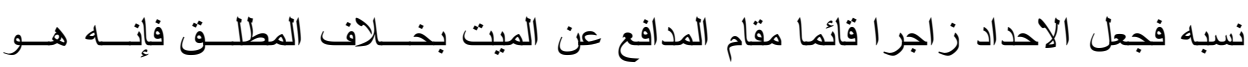

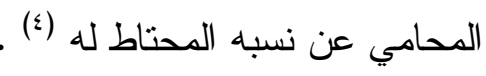

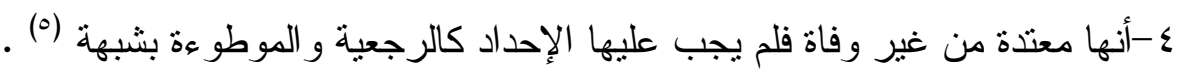

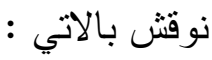
بانه قياس مع الفارق فإن الرجعية زوجة و الموطو ءة بشُبهة لبست معتدة من نكــاح فلــم

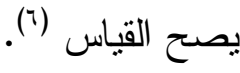
يجاب عنه : بأن المطلقة البائنة معتدة فيقاس عليها المختلعة و الملاعنة ولم يقل أحد من أهل العلم أنه يجب عليهن الإحداد فكنلك المطلقة (v).

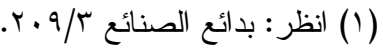

(r)

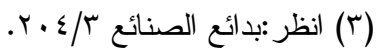

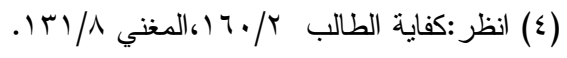

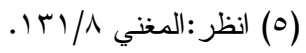

(T) انظر :المرجع السابق الصفحة نفسها.

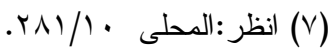


ه-أن الله فرق بين عدة المتوفي عنها زوجها وبين عدة المبتوته فعــدة المتـوفي عنهــا

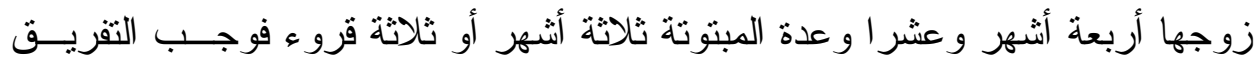

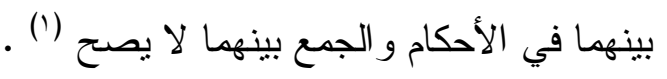

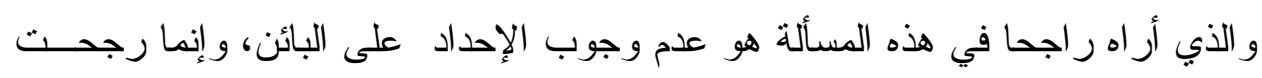
هذا القول لما يأتي:

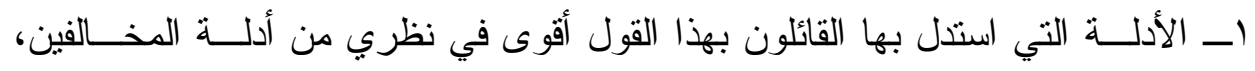

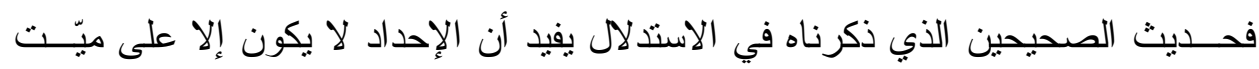

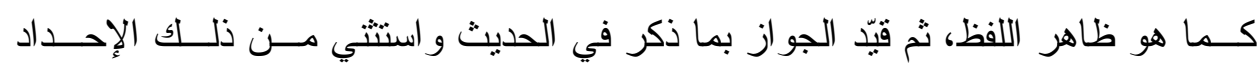

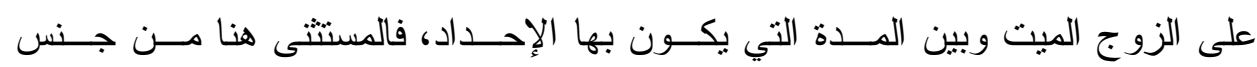

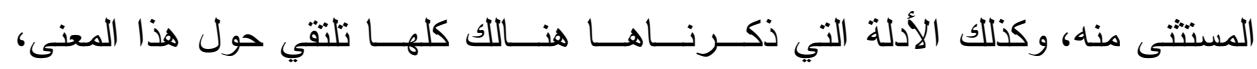

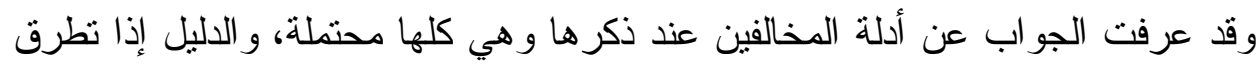
إلبه الاحتمال بطل به ولبه

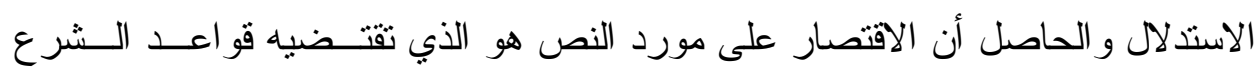

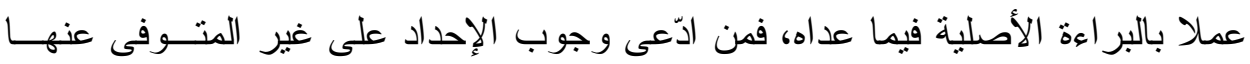
زوجها فع باليز 


\section{الخاتمة}

الحمد لله الذي بنعمته تتم الصـالحات، و الصـلاة و السلام علــى رســـوله الأمــين،

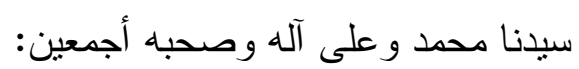

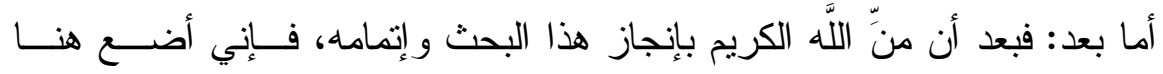

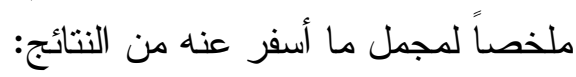

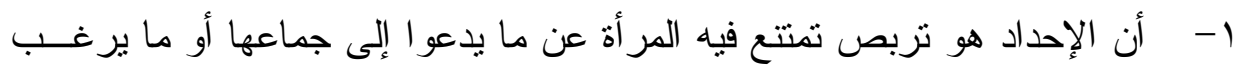

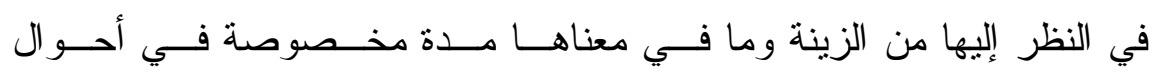
مخصوصة. r- أن الطلاق هو حل قيد النكاح بلفظ مخصوص .

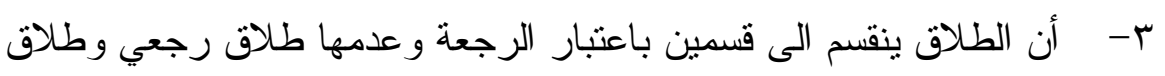
بائن.

ع- أن الطلاق الرجعي هو إبقاء النكاح على ماكان مادامت الزوجة في العدة .

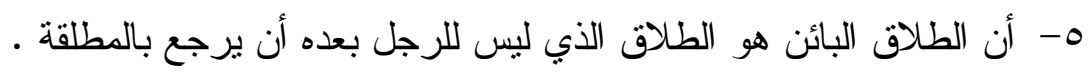

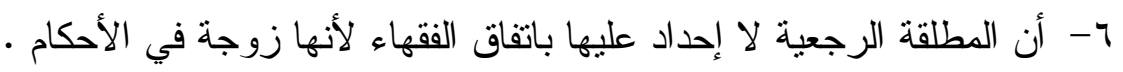

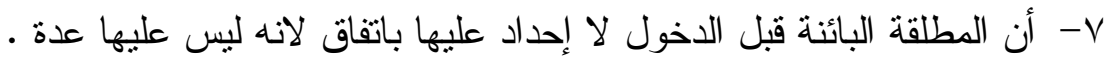
1- أن المطلقة البائنة بعد الدخول لا إحداد عليها في القول الر اجح من أقو ال الققهاء. وأختم بهذه التوصيات :

11 - أوصي بتكثيف البحوث و الدر اسات حول هذه المسائل الفقهية وما شابهها. r I أوصي بدر اسة الأحكام المترنبة على الطلاق در اسة فقهية مقارنة موسعة. و الحمد للَّه رب العالمين. 


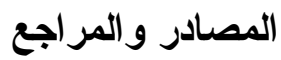

$$
\text { القر آن الكريم. }
$$

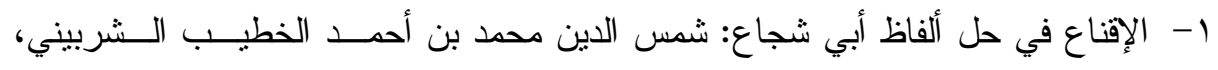

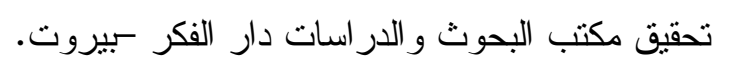

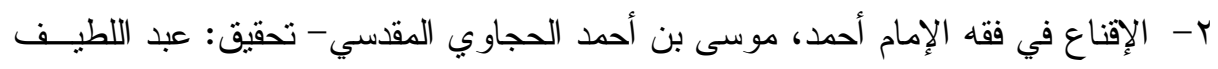

$$
\text { السبكي، دار المعرفة سبيروت لـبنان. }
$$

r- الأم، الثافعي أبو عبد اللَّه محد بن إدريس الثشافعي، دار المعرفة - بدون طبعة سنة

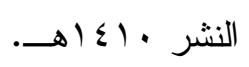

ع- الإنصاف في معرفة الر اجع من الخلاف، علاء الدين أبو الحـسن علــي المــردواي

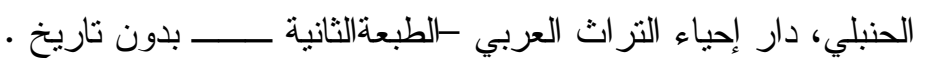

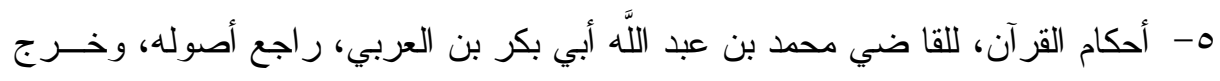

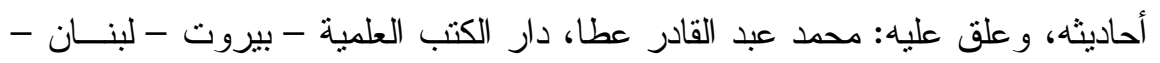

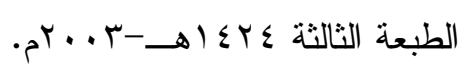

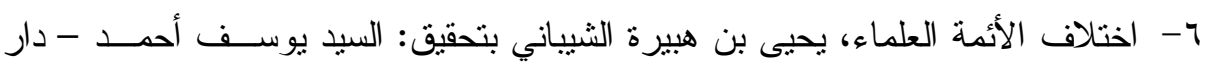

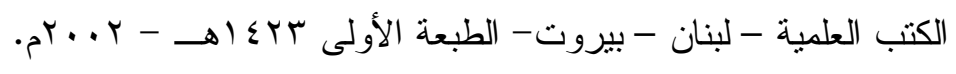

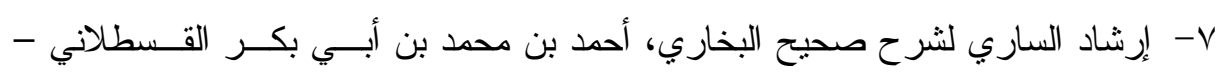

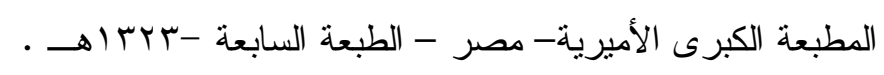

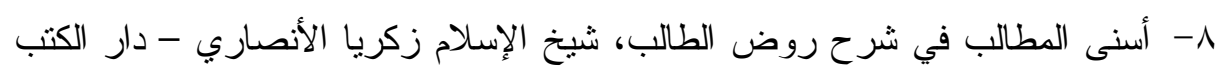

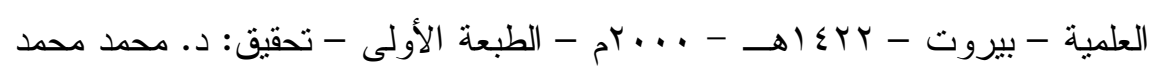
تامر .

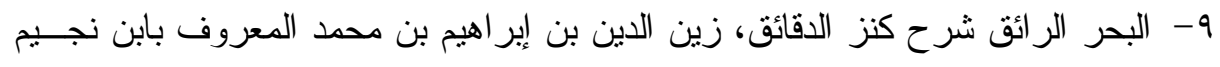

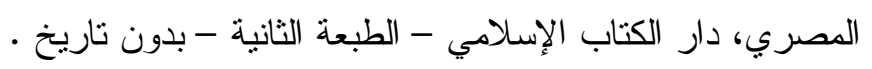

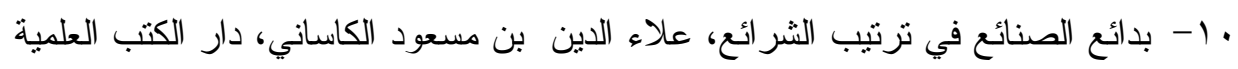

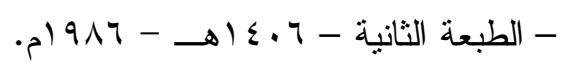

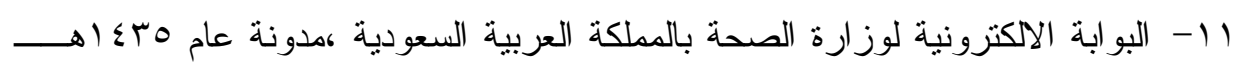

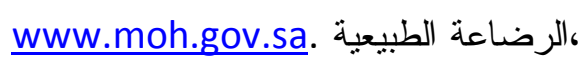


rا باج العروس من جواهر القاموس، محمد بن محمد الحسيني الزبيدي، تحقيق مجموعة من المحققين، دار الهداية.

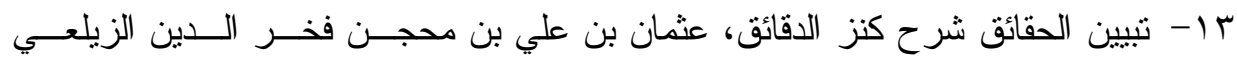

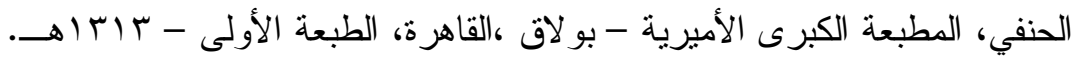

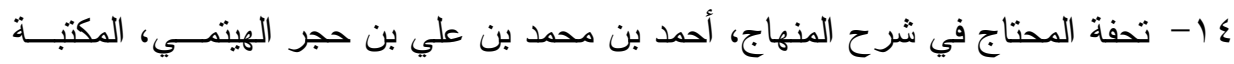

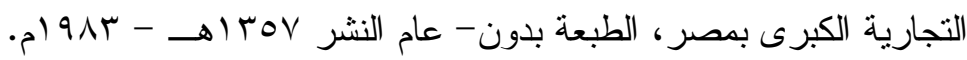

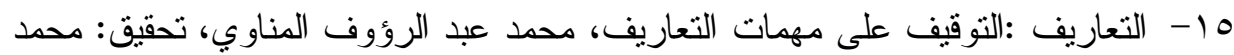

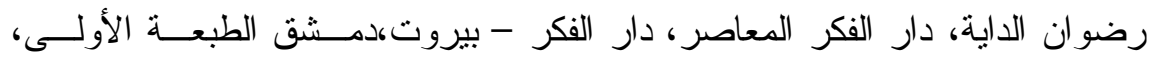
.

17 - تفسير ابن كثير ، عماد الدين أبو الفداء إسماعيل بن كثير الدمشقي، تحقيق: مـصطفى

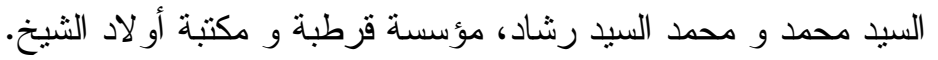

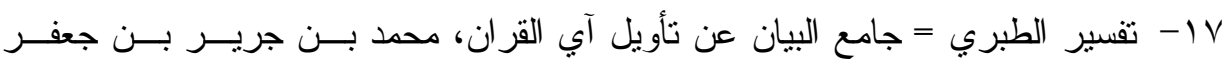

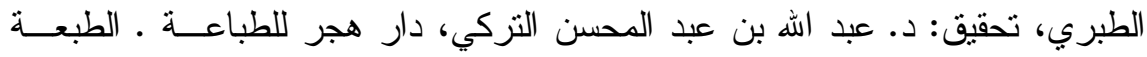

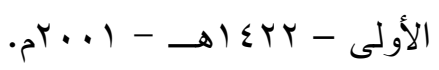

11 - التتبيه في الفقه الثافعي، أبي اسحاق إبر اهيم بن علي الثيرازي، عالم الكتب - الطبعة بدون. 9 1 - توضيح الاحكام من بلوغ المر ام ،عبداله بن عبدالرحمن البسام ،مكتبة الاسدي - مكة

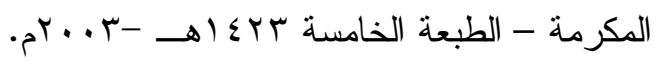

• ץ- حاثية ابن عابدين = رد المحتار على الدار المختار ، ابن عابدين محمد أمين بن عمر اهر

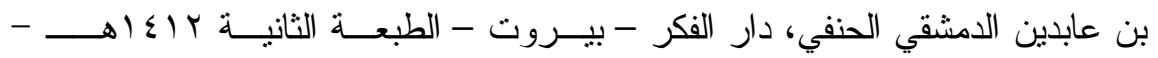
.01994

اب- حانشية الدسوقي على الثرح الكبير، محمد عرفة الدسوقي - تحقيق: محمد عليش، دار

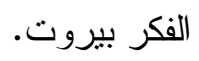

بr- الحاوي الكبير، أبي الحسن علي بن محمد البغدادي المشهور بالماوردي - دار الفكـر - بيروت.

بr- درر الحكام شرح غرر الأحكام، محمد بن فر امرز بن علي الشهير بملا خـسرو، دار إحياء الكتب العربية . 
ع ז- الذخيرة، أبي العباس شهاب الدين أحمد بن إدريس المالكي الشهير بالقر افي، تحقيـق : محمد حجي و سعيد غراب، دار الغرب الإسلامي - بيروت، الطبعة الأولى ؟99 99 ام.

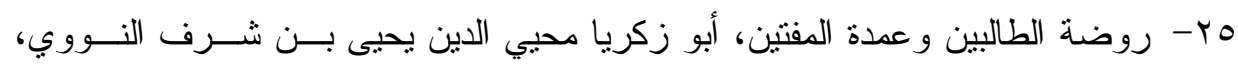

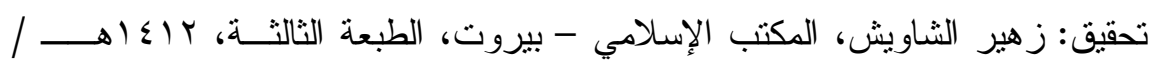
.01991

جr- سنن الدارقطني، أبي الحسن علي بن عمر بن أحمد بن دينار البغدادي، تحقيق: شعيب

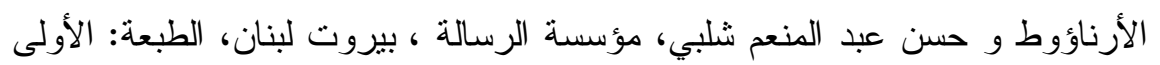

$$
\text { . }
$$

VV - الثرح الكبير على مختصر خليل، أحمد الدردير، دار الفكر ـ الطبعة: بـدون طبعـة، وبدون تاريخ.

^ץ- الثرح الكبير على منن المقنع، عبد الرحمن بن محمد بن أحمد بن قدامة المقدسي، دار

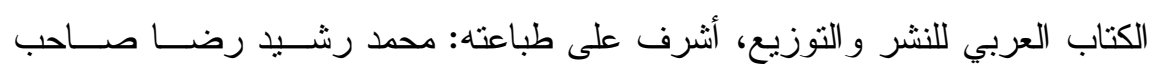
المنار .

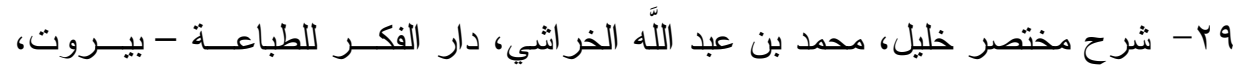
الطبعة: بدون طبعة وبدون تاريخ.

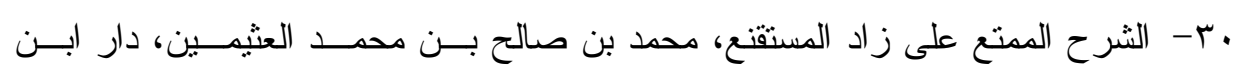

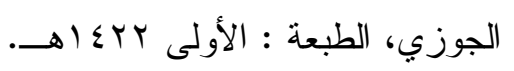

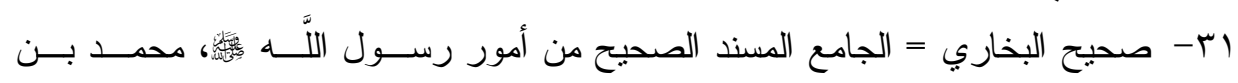

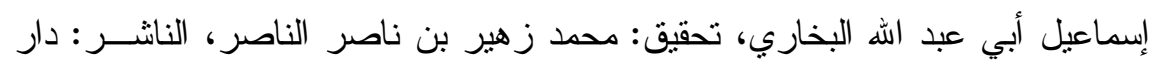

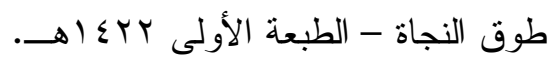

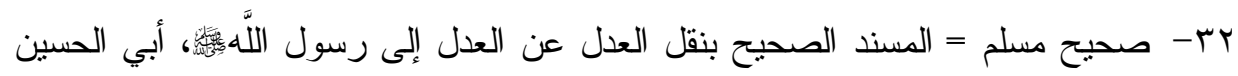

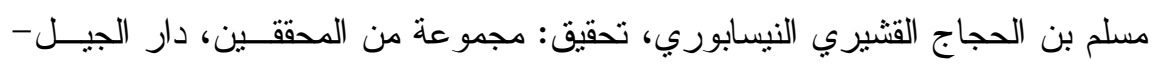

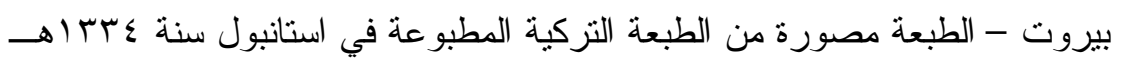

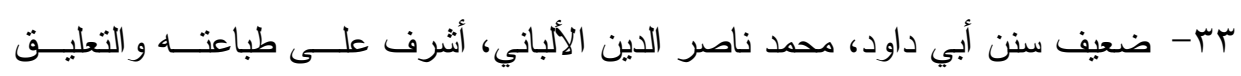

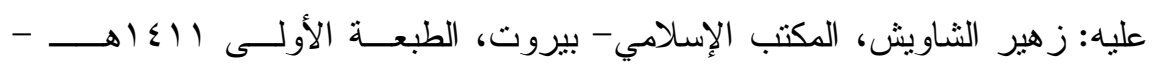


ع ז- العين، أبو عبد الرحمن الخليل بن أحمد بي عمرو بن تميم البصري، تحقيق: د. مهدي المخزومي، دار ومكتبة الهلال.

هب- فتاوى الاسلام سؤال وجو اب ،محمد صالح المنجد ،المكتبة الثاملة .

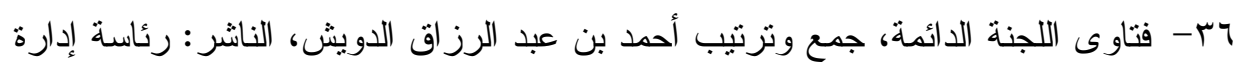

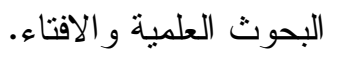
V V- الفقه الإسلامي و أدلته، د. و هبة بن مصطفى الزحيلي، دار الفكر - سورية - دمـشق،

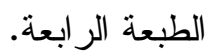

مبץ- الفقه المنهجي على مذهب الإمام الثافعي، مصطفى الخن و مصطفى البخــا و علــي

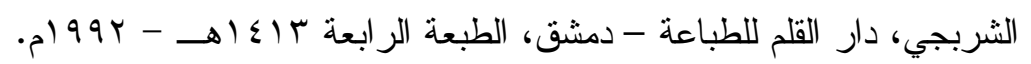

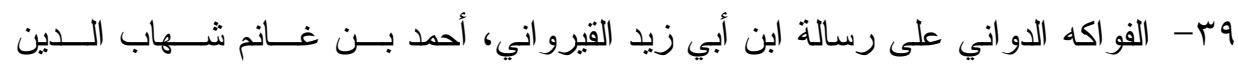

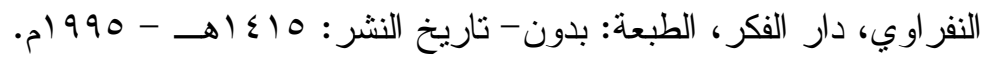

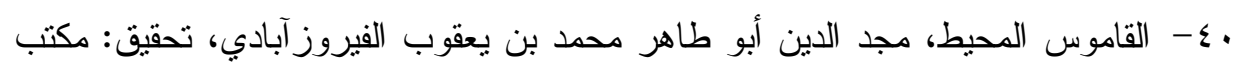
تحقيق التز اث. الناشر : مؤسسة الرسالة - بيروت- لبنان - الطبعة الثامنة.

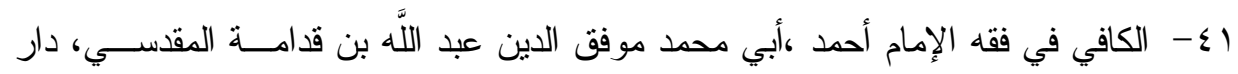

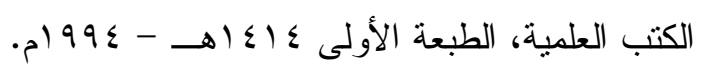

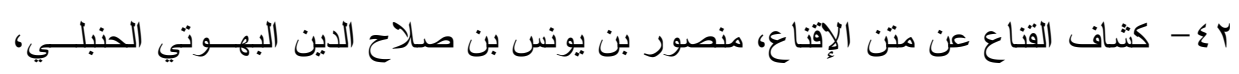
دار الكتب العلمية، بيروت. بـ - لا ضرر و لا ضرار في الإسلام، أبو سعد محمد شتا، مطابع: الناشر العربي- القاهرة . 9197 ،

؟ - لسان الحكام في معرفة الأحكام، أحمد بن محمد أبي الوليد ابن الثحنة الحلبي، النانر :

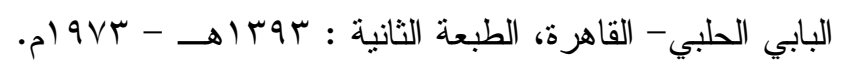

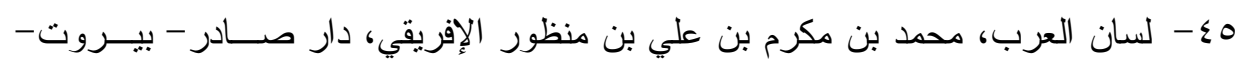

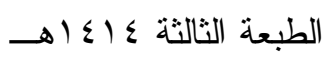

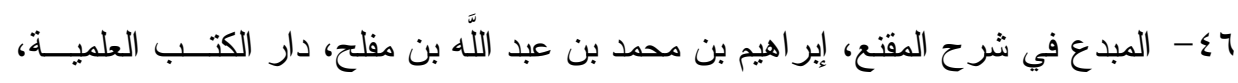

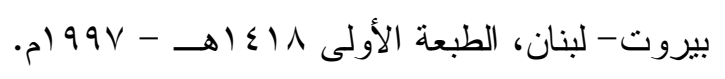

V V - المبسوط، محمد بن أحمد بن أبي سهل شمس الدين السرخسي، دار المعرفة - بيروت،

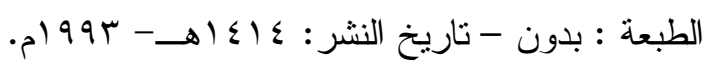


^ــ - مجلة البحوث الفقهية المعاصرة، المملكة العربية السعودية - الرياض- حي العقيق شار ع التحلية.

؟ - مجلة مجمع الفقه الإسلامي، تصدر عن منظمة المؤتمر الإسلامي بجدة.

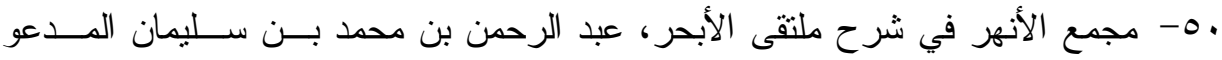

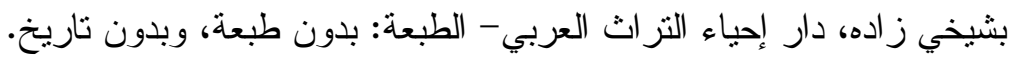

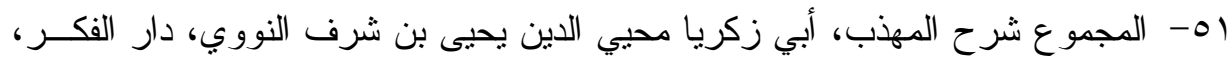

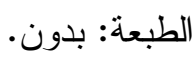

ror- مجموع الفتاوى، تقي الدين أبي العباس أحمد بن عبد الحليم بن تيمية الحراني، تحقيق:

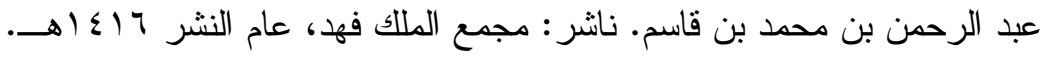

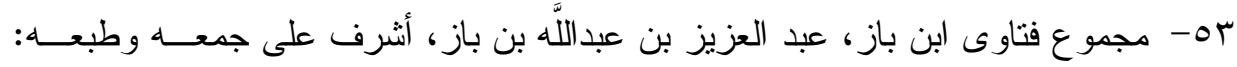
محمد بن سعد الثويعر . مجن. عه- المجموع المذهب في قو اعد المذهب، صلاح الدين العلائي، تحقيق: سر اج الدين بـن بلال، رسالة مقدمة لنيل الماجستير - إثر اف محمد بن حمود

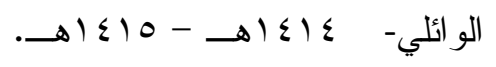
00- المدونة، ماللك بن أنس بن مالك بن عامر الأصبحي، دار الكتهـب العلميــة- الطبعــهـ

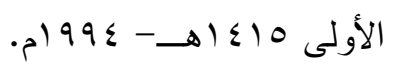

40- مسائل الإمام أحمد بن حنبل، رواية إسحاق بن منصور المعروف بالكوسج، الناثـــر :

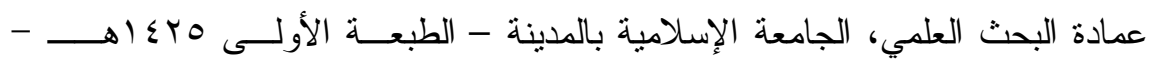
$\cdot r$ r. r

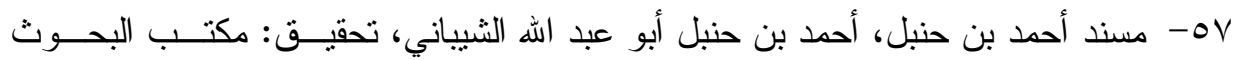

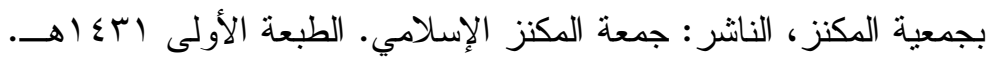

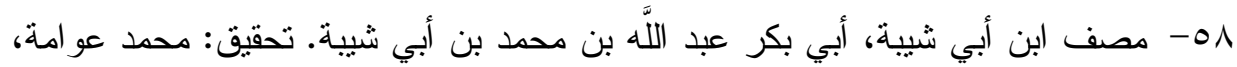
طبعة الدار السلفية الهندية القديمة. 99- معجم لغة الفقهاء، محمد رواس قلعجي و حامد صـادق قتبس، دار النفائس للطباعــة،

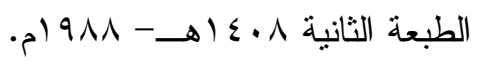
• 7- المعجم الوسيط، مجمع اللغة العربية بالقاهرة، دار الدعوة. 
ال7- المغني، أبي محمد موفق الدين عبد اللَّه بن قدامة المقدس، مكتبة القــاهرة، الطبعـة:

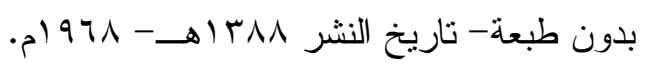

rا7- مقاييس اللغة، أحمد بن فارس بن زكريا الر ازي، تحقيق: عبد السلام محمد هـارون.

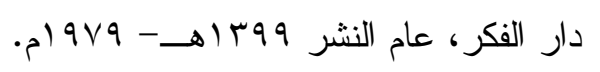

با7- الموسوعه العربية الحرة، موسوعة ويكيبيديا العربية.

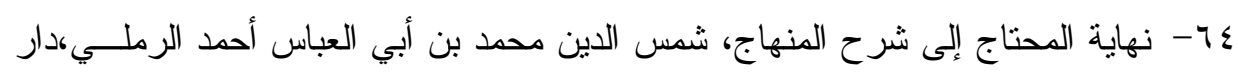

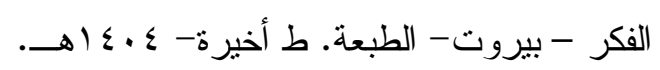

10- الوسيط في المذهب، أبي حامد محمد بن محمد الغزالي، تحقيق: أحمد محمود ابــر اهيم

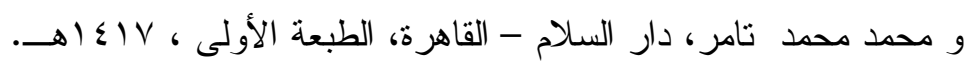


